\title{
Master of re-invention elected to CMA helm
}

I t's probably safe to say that there has never been a president of the Canadian Medical Association who used his own diamond blade saw to craft his own little stone jail.

It's apparently 10 feet by 10 feet and fitted with steel bars, a rock solid door crafted by a blacksmith friend from Nova Scotia and keys that can be heaved into the trees on his Sherwood Park, Alberta, acreage, should he feel inclined to do so after tossing a guest or two - or the odd policeman, as he has been known do in the past -into the hoosegow. The gaol, though, has a cedar roof, so it probably wouldn't be all too difficult for a miscreant to eventually escape in the event he was no longer in Dr. Louis Hugo Francescutti's good graces.

Odd though it sounds, the fact that Francescutti is an amateur stonemason with plans to build his own little stone town - complete with doctor's office, school, bank, store and a replica of a French-Canadian farmhouse - may not be his largest idiosyncrasy.

Try these for rare combinations, for an emergency physician.

Francescutti holds an MD and a $\mathrm{PhD}$ in medical sciences (immunology) from the University of Alberta and a master's in public health with a specialization in health policy and management from Johns Hopkins University in Baltimore, Maryland.

He's the current president of the Royal College of Physicians and Surgeons of Canada (his two-year term expires in February 2013) and has a passion for governance. "Recently, I did the Institute of Corporate Directors' director's program. So governance is something that I love because I think we do it so poorly. And so I love anything that's got to do with governance. I think chairing a meeting is like leading an orchestra because there's so many different players."

He was on a surgery track before foraying to Baltimore and ultimately completing a preventive medicine residency. "Hopkins really made me understand

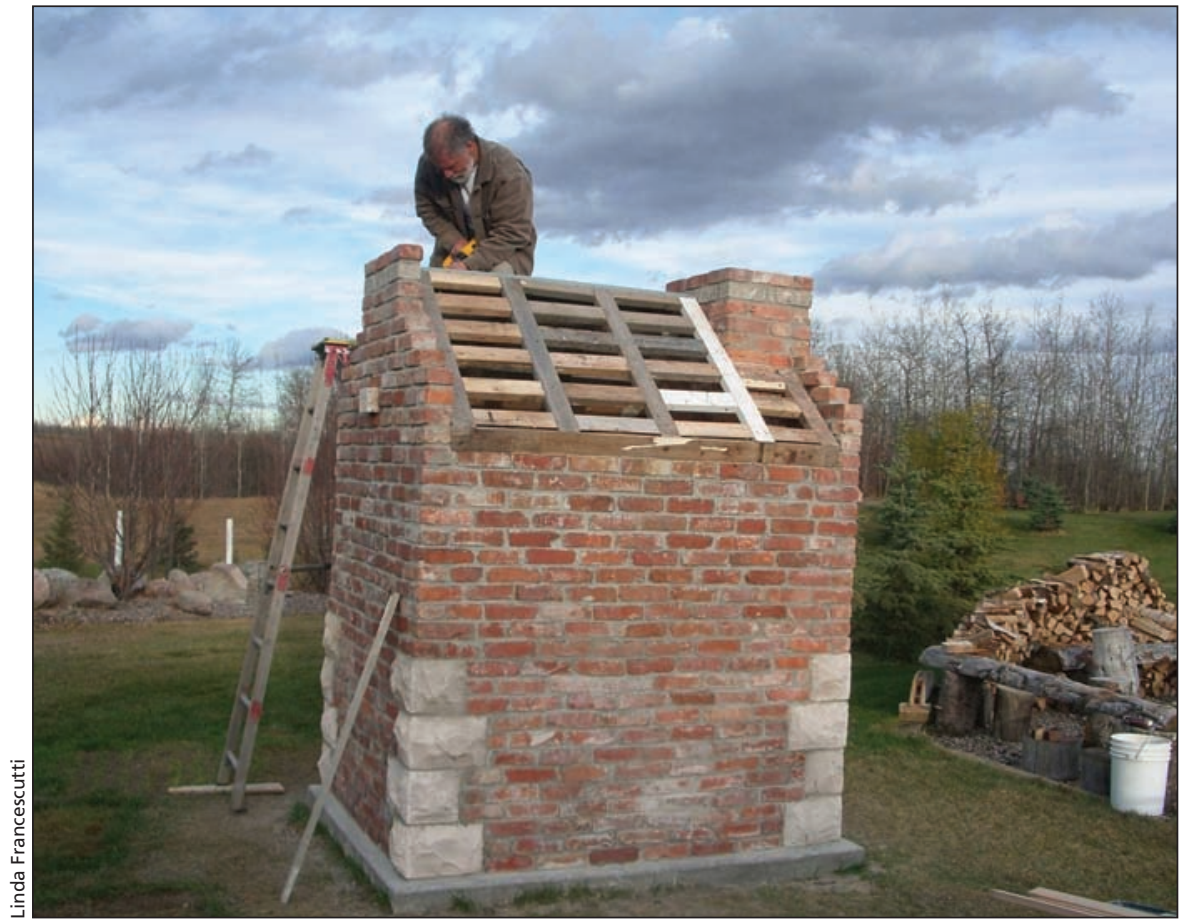

Among CMA President-Elect Dr. Louis Hugo Francescutti's many skills is stonemasonry, as anyone who has seen the outdoor brick oven on his property in Sherwood Park, Alberta, already knows.

that life's very short and if you're going to make a difference, you better pick an area that you can have the maximum impact, so as a surgeon maybe I would have saved maybe 300 lives, as a result of trauma. But as a preventionist, I could probably save thousands of lives."

$\mathrm{He}$ is a tenured professor in the School of Public Health at the University of Alberta, an emergency physician at the Royal Alexandra Hospital and the Northeast Community Health Centre in Edmonton and the founder of both Injury Alberta and the Coalition for Cellphone-Free Driving.

His lengthy curriculum vitae includes stints with Accreditation Canada; as a medical columnist for the Canadian Broadcasting Corporation; and a host of other seemingly unrelated positions, awards and credits. He lists as his special interests "creating full-sized waterfalls, building sheds, raising trees of all kinds, stone masonry, continuously refining an outdoor hockey rink, build- ing outdoor wood fired ovens and enjoying the family [spouse Linda and children Louis Jr., Luciano and Laura] on our acreage."

So what might conceivably be the self-description of this man who clearly constantly re-invents himself?

"Storyteller."

As such, Francescutti says he'll be assuming the presidency of the CMA at a perfect time in August 2013, as the association will likely be leading a charge to redress health inequities in Canada and will most need a storyteller to make the case to politicians and Canadians.

"That's what I specialize in," he says. "Everyone wants to listen to a story. The human brain is programmed so that when it hears a voice, to pay attention to it. That's how we've survived. Because we were hunter-gatherers not very long ago. All these gadgets that we have now are foreign to us. So the thing that got us this far was stories: Let me tell you where I found food 
today. Let me tell you where shelter is. Let me tell you where the animals are living. So the verbal communication is so important to us. So this [health inequities and a need to bolster preventive medicine] is a story that is waiting to be told."

"When you're a good storyteller, it's like you go into slow motion," he adds. "Sports athletes describe it. They're in the moment. You've got a million things going on and after you tell your story, you've got a wicked headache because your brain is working really hard. But this is a story that's waiting to be told and the audience could be physicians, could be politicians, could be patients, could be policy-makers, could be the media. There's a lot of people that are waiting to hear this story. And I think that physicians are poised to take the lead in society and say, you know, medicine can do a lot. We can do a lot of pretty miraculous things but what we're starting to discover is that maybe we need to reinvent ourselves as a profession and really try and make sure that people are as absolutely healthy as they can be and to get them there, it may take more than scalpels and pills, and so how can we, how do we develop the tools and how do we share those tools with physicians so that a) they feel they should be doing something and b) they feel they have the skill sets to do it properly."
But it's a preventionist's dream, Francescutti says. "After going to Johns Hopkins and doing a master's in public health and a preventative medicine residency, it was almost as if I was debrainwashed from four years of medical school and I realized what was really important in making people healthy. The health care system is fantastic once you're sick. But the whole notion of trying to prevent you from getting sick in the first place is a foreign concept to most physicians."

Yet, "that's the kind of stuff I eat, live and breathe," he adds. — Wayne Kondro, CMAJ

CMAJ 2012. DOI:10.1503/cmaj.109-4274 